\title{
Resonance as an integral part of human resilience
}

\author{
Bojan Zalec
}

DOI: 10.18355/XL.2021.14.03.13

\begin{abstract}
The author analyses the relationship between the concepts of resilience and resonance. $\mathrm{He}$ argues for the thesis that resonance is an integral part of the genuine human resilience. Therefore, there is no contradiction between resonance and resilience if we understand these two concepts correctly. The opposite arises only if we understand resilience as a kind of robust and rigid resistance, but which, as the author argues, does not correspond to the notion of true human resilience. Since resonance is an integral part of human resilience, we can say that human resilience depends on their being in resonance relationships. The understanding of the resonance that the author takes for the grounding of his main thesis was developed by German sociologist Hartmut Rosa. Thus the paper includes also the presentation of Rosa's conception of resonance and his theory of our relationship to the world. Despite the focus on the main thesis, the article is not only a contribution to the understanding of resilience, but also enriches the understanding of (Rosa's) notion of resonance by showing its importance for resilience. The author argues that classical theological virtues (faith, hope, and charity (love)) can be positive factors of human resilience, and illuminates them from the point of view of resonance.
\end{abstract}

Key words: resilience, resonance, theological virtues, Hartmut Rosa, our relationship to the world

\section{Introduction}

In this article, I analyse the relationship between the concepts of resilience and resonance. In doing so, I confine myself to comparing these two concepts insofar as they are applied to man. Therefore, the more precise formulation of the topic of the article is: the relationship between human resilience and resonance. The main thesis I will argue for is that resonance is an integral part of the genuine human resilience. Therefore, there is no contradiction between resonance and resilience if we understand these two concepts correctly. The opposite arises only if we understand resilience as a kind of robust and rigid resistance, which, as I argue, does not correspond to the notion of genuine human resilience. Since resonance is an integral part of human resilience, we can say that human resilience depends on their being in resonance relationships.

The article has the following structure. In the first part, I present the concept of resilience. In the second part, I present the concept of resonance. From these presentations, the justification and truth of my main thesis becomes clear.

The subject of the article is extremely relevant and topical. The notion of resonance I present here was developed by the German sociologist Hartmut Rosa (Rosa, 2016; 2019a; 2019b; 2019c). Rosa has arisen tremendous interest in his resonance theory in recent years (Peters, Schulz, 2017; Kladen, Schußler, 2017; Wils, 2019; Rosa, Henning, 2019; Klun, 2020). The topic of resonance has become one of the hottest topics at the moment, thanks to him. This is not surprising, as an in-depth and correct understanding of resonance is crucial for understanding and solving the key and fundamental problems of the modern world. These occur at different levels. At the most fundamental and global level, we can mention the ecological challenge. We urgently need a change in attitude towards the natural environment: not only at the level of individuals and certain groups, but at a massive, sociologically relevant level.

XLinguae, Volume 14 Issue 3, June 2021, ISSN 1337-8384, eISSN 2453-711X 
Resonance attitude towards the natural environment is a good foundation for such a new attitude. At the social level, we can mention the problem of anti-democratic populist movements threatening our, Western, liberal democracy. As Charles Taylor (Taylor, 2019: 75-79) pointed out, these movements cannot be understood properly without the notion of resonance.

The same is true of the concept of resilience, which is nowadays used in many different fields and in many scientific disciplines (Vogt - Schneider, 2016). Resilience is the name for a new paradigm of thinking and acting (Graefe, 2019: 205-207) needed to cope with challenges in a world that is changing faster, is less and less transparent and increasingly unpredictable (Vogt, 2015: 15; Ambrosy et al., 2020; Nguyen, Valcova et al., 2020; Nguyen, Truong et al., 2020). That's why Jeremy Rifkin (Rifkin, 2020) points out that it's imperative that we move into an era of resilience and that we've already entered it. As I show in the article, resilience and resonance are closely intertwined, so a comparative treatment of the two is useful for their in-depth understanding and is actually necessary for it.

I also prove my main thesis by exploring the three classical theological virtues, faith, hope and love, as positive factors of resilience, illuminating them also from the point of view of resonance. The example of theological virtues is suitable for my proof, where resonance and resilience are especially strongly and completely intertwined in religion, which already shows the importance of researching resilience and resonance for religion and its sciences (philosophy of religion, theology, religious studies, etc.).

\section{Resilience}

The term resilience comes from the Latin word "re-silire", which means "to leap back" (Vogt - Schneider 2016: 182). This etymology itself shows quite well the true meaning of the word resilience. The appropriate metaphor for resilience is not a robust tank or an oak, but a lithe tree or grassy plant that bends in strong winds, but over time returns undamaged to its previous state. The main characteristics of resilience are, in addition to durability, flexibility as well as appropriate capability of transformation. Resilience is the proper combination or proportion between the transformation and the preservation of the identity of an entity (organism, person or system), where it is not always easy to answer whether the entity has retained the identity after the transformation. Resilience strategies take into account unforeseen and not yet seen or unexperienced events. Strengthening resilience means strengthening preparedness for unknown problems. Resilient entity will not be completely thrown off track by surprise or ambivalence even if it is vulnerable. In this sense, the ability to adapt, improvise, ingenuity, and be prepared for surprises are among the leading virtues of resilient entity. Therefore, in a world that is increasingly complex, non-transparent and unpredictable, and which is changing extremely fast, resilience is more and more important.

From the resilience point of view lack of security, crises, ruptures, etc. are not necessarily a bad thing. Moreover, crises are, in a sense, necessary, as they have being appropriately processed - strengthening effects. They give an impetus in the direction of higher complexity (Horx, 2011: 36) and thus they are practically necessary for the development of complex living or social systems. In this sense, the central issue of the resilience perspective is not the provision of integrity and some stable security and protection arrangements, but the role of tensions, ruptures and crises in the development of systems and survival, and self-preservation of an otherwise vulnerable system in unstable and unpredictable (new) conditions. Resilience is the ability of an entity to preserve itself despite its vulnerability and injuries. Resilience is a crisis concept (Sautermeister, 2016: 211; Petkovsek, 2019), as it is unintelligible without the concepts of problem, affliction, challenge, or crisis. We start talking about resilience in times of crisis, and its increased use is an indicator of the onset of the crisis. Speaking of resilience is a crisis discourse. 
For an entity to survive, it must be able not only to adapt and be durable, but also to transform. This applies to both the individual and society. With the consideration of change and preservation, however, we have already touched the normative aspect of resilience. To assess the desirability or undesirability of conservation and change, and thus resilience, we need to refer to certain values. At the level of society, the leading civilizational values, such as human dignity, freedom, humanity and responsibility to the environment or creation are essential here. Resilience is also closely linked to justice. Normatively, resilience is desirable only if it is compatible with the abovementioned values and principles. (Vogt, Schneider, 2016: 189-190)

The question that arises for a researcher of virtues and a theologian in the context of resilience is: How can classical theological virtues - faith, hope and love - contribute to resilience? Our starting point is that the importance of religious traditions and reflections is not in providing of direct solutions to problems, but on the meta-level: they help to shape mental and spiritual infrastructures, basic attitudes and patterns of experience needed to seek solutions with the right perspective. (Schneider - Vogt, 2016: 196) In line with this premise, I will examine below how human fundamental attitudes are related to faith, hope, and love. The hypothesis I will argue for is that active and living faith is the source of human resilience, as the two other theological virtues are.

Let's start our reflection on faith with the reflection on trust. The biblical term for faith is "aman." "Aman" means to rely on God. Faith is closely intertwined with trust in God. From this point of view we can conclude that faith is the source of human strength, as man relies on the reliability of God to develop his own strength, reliability and endurance. (Hieke, 2009: 27) This finding can be further substantiated and deepened by considering the importance of man's sense of the coherence of the world and life, and the connection of this sense with faith.

The sense of coherence occupies a central place in the salutogenesis approach developed by medical sociologist Aaron Antonovsky. (Antonovsky, 1979; Schneider, Vogt, 2016: 198) Antonovsky highlighted three central health factors: comprehensibility, manageability, and meaningfulness (Antonovsky 1997: 34). Comprehensibility or the capability to understand denotes person's ability to look at their life, world, successes, as well as their problems in a broader context. These are understandable if they are experienced as coordinated and orderly. Manageability means the belief that man can "shape" their own life. The meaningfulness component concerns the meaningfulness of human life and its engagement. Faith in God is associated with the orientation of life, which relativizes the crisis without unrealistically depriving it of a certain (potential) harm. Relativization has various aspects, of which we can highlight the following: 1 . faith is trust in the nearness or presence of God, who is not merely an uninvolved observer, but is involved in our relationship with us (Sedmak, 2013: 275; Roubalova et al., 2020: 199-203); 2. a believer can relativize because they are able to place things in a broader framework, a broader horizon. They can do so because they are capable of experiencing, and understanding through parables, metaphors, symbols that point to something greater and transcendent (Sedmak, 2013: 281; Vodicar, 2017: 571-573); 3. believers do not experience their own identity as their own achievement, but as something that is a gift of God (Sedmak, 2013: 284-287; Platovnjak, 2017: 341; Platovnjak, Svetelj, 2019: 674-675, 679-680; Strahovnik, 2018).

"Relativizing" the meaning of oneself, things, events, and problems associated with faith implies a certain spiritual peace and serenity, Ger. Gelassenheit (Schneider Vogt, 2016: 199). We can point out the following "paradox": this calmness does not lead to a passive attitude, but enables readiness for action, which is not exhausted in empty and shallow short-breath activism, but is based on trust in God, which gives meaning to action (Pavlikova - Mahrik, 2020: 152) and it also allows one to

XLinguae, Volume 14 Issue 3, June 2021, ISSN 1337-8384, eISSN 2453-711X 
overcome seemingly unsolvable problems. This serenity protects people from the danger of striving for too much control. Here we can mention the "paradox" that too much striving for control causes the loss of control: one who tries to have everything under control cannot let anything flow, neither to themselves nor to those around them. This causes paralysis. Thus we see that the cause of the blockage of action is not serenity, but lack of serenity. The illusion of control, which wants to rule out any uncertainty and wants to control everything, ultimately causes paralysis. Conversely, trust has a similar effect as serenity, which allows itself and its surroundings to go their own way. Only those who trust in the load-bearing capacity of the ground can move forward. Those who have no confidence are overcome by some indefinite, vague, and crippling fear or anxiety. The ability to act indicates the trust it presupposes.

Comprehensibility, manageability and meaningfulness are associated with an "optimistic" attitude. By this we mean the confidence that things will somehow move forward, that the person still has something ahead of them, that they can and must do something more of themselves, that they can still start something new, that there is still some task ahead of them. This all means that they see the point, that life makes sense for them. We call this future-oriented trust hope. (Schneider - Vogt, 2016: 199) If we consider that the feeling that something is possible and the willingness to act are components of the ability to act, then we can say that hope is one of the key sources of resilience (Sedmak, 2013: 317). Hope is a central force that allows a person to be active (Bogaczyk, Vormayr, 2012: 16).

The concept of maturation is very important for the correct understanding of the relationship between resilience and vulnerability. The argument is this: only those who are vulnerable, those who can suffer injuries, only those who can be affected are able to mature. Maturation, however, is what really makes a person resilient. Maturation is theologically interpreted as openness to the radically other, that is to God, and through this openness, weakness is transformed into strength. We can also read about this in The Second Letter to the Corinthians of the Apostle Paul: "Because when I am weak, I am strong « (2 Cor 12:10).

Resilience is thus more than mere security and protection from injury. Moreover, vulnerability is a condition for truly developed and complete resilience. At this point, we can connect our reflection with love, as love is essentially openness and at the same time a transforming power. One who loves opens themselves to the beloved being. When we love, a kind of connection is formed between us. Rosa calls this phenomenon "resonance". In resonance, the other enters into such a relationship with me that I change with it. Love is a power that transforms. (Schneider - Vogt, 2016: 203) Love goes beyond the pursuit of security, control, and protection from injury, and pushes us toward liberation from fear, which hinders solidarity with others. Love is a dialogical attitude towards the world, marked by responsiveness and resonance. Through love, things and people gain meaning or sense (Sedmak, 2013: 349). The aforementioned qualities of love show that love implies resilience, as serenity, freedom from fear, and meaningfulness are characteristics and factors of a resilient personality.

Summing up our reflection on theological virtues and resilience, we can say the following: true Christian virtues are those capabilities that relativize merely worldly fear, free us from it, motivate us to look critically and at the same time realistically, and allow us to act freely and turn to others. Those who trust God and allow themselves to be carried by their love can walk through life with confidence, accept challenges "calmly", and know how to live with uncertainty. Faith frees us from being imbued with the fear that everything must be under our control. Hope motivates us to trust, which does not allow one to break down in the face of supposedly unchangeable facts (Tavilla - Kralik - Roubalova, 2019). The one who has hope sees a perspective for action and a space for their own action. The driving force that gives weight to the 
whole, however, is love. They who love open themselves to the joys, hopes, worries, and distresses of other people and are able to be in a resonance relationship with them. For the one who loves, others and the world, despite their shortcomings, are interesting, encouraging and inspiring. (Schneider - Vogt, 2016: 203-4). Only for such a man, however, life can make sense. That is why love is the creation of meaning. The topic of meaning, however, guides us to the topic of authenticity, as the two are closely connected.

Not only resonance with the other is important for resilience, but also resonance with oneself, with one's own being. This resonance is called authenticity. Authenticity is an integral part of a truly resilient subject. Authenticity should not be equated with any rigid resistance to any transformation, but with the ability to transform properly, which nevertheless maintains the continuity of the subject on the basis of its core components.

Religious attitudes and practices that liberate from fear point to the understanding of resilience, which is more than just about protecting one's own identity. A dialogical relationship with the world is of constitutive importance for this. We will not only defend ourselves against challenges and dangers in this perspective, but we will also accept them in readiness to transform ourselves and as opportunities for learning. In Catholic theology, the term "signs of the times" has become established to speak of such an attitude toward the world. The term "signs of the times" is characterized by a "question-answer" dialogic scheme, as the starting point of the paradigm of the signs of the times is represented by concrete human questions that need to be answered. This responsive attitude can also be interpreted as a strategy of resilience (Schneider Vogt, 2016, 204), as responsiveness, as we have seen, is a fundamental component of resilience as a competence to be able to cope with unforeseen events, disturbances and structural ruptures such as we have not known yet. Responding to them is not limited to short-term defence, but includes also learning how to live in changed conditions in the long run. In such an attitude, we take into account the in depth dimensions and the changing effects of challenges, and from all this we draw consequences for ourselves and for our own system. In addition, resilience is significantly related to authenticity as a dynamic fidelity to one's own being or identity that implies the ability to transform because, as already mentioned, being authentic does not mean immutability, but, on the contrary, implies the ability to transform properly.

\section{Resonance}

Rosa has presented his notion of resonance and the resonance sociology of our relationship to the world in various publications. The most important is Rosa (2016) (English translation Rosa, 2019c). Rosa has developed a relational theory of our being-in-the-world. This theory draws from various sources and combines the elements thus obtained into an integral theory. Perhaps for some, Rosa's affiliation with the Critical Theory is most notable, but his theory also owes much to various other thought currents: phenomenology, personalism, and relational thought in general. Of the Critical Theory, Herbert Marcuse, Theodor W. Adorno, and Erich Fromm should be mentioned first, of phenomenologists Martin Heidegger, and of personalists Martin Buber.

Rosa developed a special model of being-in-the-world (Rosa, 2019b: 197-198; 2019c: 145) that overcomes subject-object dualism. This, of course, immediately reminds us of Heidegger. Rosa highlights four constitutive moments of resonance (Rosa, 2019b: 196): 1. affection (Ger. Affizierung); 2. self-efficacy (Ger. Selbstwirksamkeit); 3. transformation (Ger. Transformation); 4. inaccessibility (Ger. Unverfügbarkeit) (Rosa, 2018; 2019d). The last moment points to another similarity between Rosa's theory and Heidegger's philosophy.

XLinguae, Volume 14 Issue 3, June 2021, ISSN 1337-8384, eISSN 2453-711X 
Affection means that resonance is the opposite of non-influence, indifference and the similar. We cannot talk about resonance if both participants in the relationship are not affected. It is very important to be aware that resonance is a two-way or two-sided relationship. (Rosa, 2019a: 27) This, in turn, directs us to the second constitutive moment, self-efficacy. This means that no participant in a resonance relationship is passive, inactive. In resonance, no participant is merely an object, but each participant is a subject. This is a similarity between resonance and Buber's I-Thou relationship. This is a very similar, if not quite the same, point. According to Buber, in the I-Thou relationship, it is not only that I explore the entity with which I am in the I-Thou relationship and it is only a passive object of my research. In the I-Thou relationship, it happens that the entity with which we are in a relationship opens up, opens up to us, illuminates itself, as Buber says (Buber, 1999: 100), in its entirety and unity (Buber, 1995: 120). The entity we "discover" is itself active, it unfolds itself, the I-Thou relationship only makes it do this (Buber, 1999: 100). An additional similarity between the I-Thou relationship and resonance is that we can have both relationships, the I-Thou relationship as Buber conceives it and the resonance as understood by Rosa, in principle, to any entity: to plants, to animals, to inanimate things, to the world as a whole, God etc. (Buber 1995: 118) Buber's example of the I-Thou relationship is, for example, the I-Thou relationship to a machine (which is increasingly relevant in today's technological age) and the relationship to world events (Buber, 1999: 152). Taking into account the outlined understanding of I-Thou relationship and resonance I think that the ecological significance of developing the IThou relationship or resonance relationship to the natural environment is at hand.

The next constitutive moment of resonance is transformation. Here again, the twosided nature of the resonance relationship comes to the fore. Resonance is a relationship that transforms both participants in it. This is another common point with Buber's I-Thou relationship. The next common feature with the I-Thou relationship is that resonance cannot be arbitrarily produced and controlled. Resonance, like the IThou relationship, eludes control. A resonance relationship therefore means a partial loss of autonomy. (Rosa, 2019a: 27)

The uncontrollability of resonance is closely related to its fourth constitutive moment, to inaccessibility (Rosa, 2019b: 200-201). In terms of inaccessibility, the distinction between appropriation and adaptive transformation is important. Appropriation is a posture or behaviour that makes a particular entity accessible. Its opposite is adaptive transformation, which is the "heart" of a resonance relationship. The adaptive transformation is an attunement with the world or a particular entity with which we are in a resonance relationship. This adjustment is transformative because it changes both participants in the relationship. It is a transformational encounter (Ger. Begegnung) between the two. (Rosa, 2019a: 14) The distinction between appropriation and adaptive transformation is the basis of Rosa's attempt to establish resonance as a central concept for the foundation of relational sociology and the philosophy of world relationships (Ibid.). The resonance relationship cannot be arbitrarily disposed of and controlled. Paradigmatic examples of a resonance relationship that can illustrate this are faith and love. Faith is in Christianity understood as the grace of God, and love strikes us in a way that is beyond our control. Also, the transformational effects of resonance spiral out of control. (Rosa, 2019a: 19) In addition, we cannot enter or be in a resonance relationship with an entity to which we take an appropriative attitude. The equivalent of the appropriative relationship in Buber is the I-It relationship, which is the opposite of the I-Thou relationship.

According to Rosa, our fundamental relationship to the world may in many respects be precognitive, but it is not presocial. This opens the horizon for a genuine sociology of human relations to the world. (Rosa, 2019c: 144).

Rosa claims that the basic categories of our relationship to the world are resonance and alienation. He defines it as follows: 
»Resonance is a kind of relationship to the world, formed through af $\leftarrow$ fect and $\mathrm{e} \rightarrow$ motion, intrinsic interest, and perceived self-efficacy, in which subject and world are mutually affected and transformed.

Resonance is not an echo, but a responsive relationship, requiring that both sides speak with their own voice. This is only possible where strong evaluations are affected. Resonance implies an aspect of constitutive inaccessibility.

Resonance relationships require that both subject and world be sufficiently 'closed' or self-consistent so as to each speak in their own voice, while also remaining open enough to be affected or reached by each other.

Resonance is not an emotional state, but a mode of relation that is neutral with respect to emotional content. This is why we can love sad stories« (Rosa, 2019c: 174).

The definition of alienation:

"Alienation denotes a specific form of relationship to the world in which subject and world confront each other with indifference or hostility (repulsion) and thus without any inner connection. Alienation can therefore also be defined as a relation of relationlessness (Rahel Jaeggi).

Alienation thus indicates a state in which the world cannot be 'adaptively transformed' and so always appears cold, rigid, repulsive, and nonresponsive. Resonance therefore constitutes the 'other' of alienation - its antithesis.

Depression or burnout refers to a state in which all axes of resonance have become mute and deaf. A person may 'have' a family, work, social clubs, religion, etc., but these no longer 'speak' to them. The subject is no longer capable of being touched or affected and lacks any sense of self-efficacy. World and subject thus both appear lifeless, dead, empty" (Rosa, 2019c: 184).

When we are in a "relationship" of alienation with the world, the world is mute, it does not talk to us and neither do we to it. (Rosa, 2019a: 16) There is no communication between us and the world. The real relationship or resonance is communication, moreover, transformational communication, while alienation, a relationless "relationship", is something dead. Alienation in this sense means the loss of the world, "Weltverlust" (Rosa, 2019a: 23); it is about losing the world as a living partner in a living relationship, not as a bare object of appropriation, availability, use, or exploitation. Buber's term for such a relationship is I-It relationship.

Rosa distinguishes three dimensions or axes of resonance: horizontal, diagonal, and vertical (Rosa, 2019c: 195ff; 2019a: 24-25). The horizontal dimension encompasses social relationships with other people, such as friendships and intimate relationships, as well as political relationships. The diagonal dimension encompasses the relationship to the world of material things. The vertical dimension (Rosa, 2019c: $258 \mathrm{ff}$ ) is the relationship to the world understood as an embracing or comprising totality (Rosa 2019a: 24-25, 28-29) that "may include other people, artifacts, and natural objects, as well as perceived totalities such as nature, the universe, history, God, life, and even one's own body and emotions. Resonance relationships thus vary according to the resonating segment of the world involved" (Rosa, 2019c: 195).

The next important fact is that resonance is not harmony or consonance, but presupposes dissonance and difference (Rosa, 2019a: 22). Rosa cites the example of dialogue as a form of resonance relationship: at least the beginning of a dialogue requires a difference, a difference that manifests itself in opposition and opposing. Without this difference, no resonance is possible (Ibid.). Resonance is neither a complete agreement, in which no real dialogue can develop, and in which meeting with another voice is missing, nor is a bare argument and accusation, where the key

XLinguae, Volume 14 Issue 3, June 2021, ISSN 1337-8384, eISSN 2453-711X 
constitutive moments of resonance - real influence or affection, self-efficacy, mutual transformation or adaptive transformation, and the relationship of non-appropriation or inaccessibility - are missing.

We have already emphasized that resonance is a two-sided relationship. (Rosa, 2019a:

27) Without willingness to resonate, certain openness to it by resonant participants, resonance is not possible. However, resonance is inaccessible and cannot be controlled. Therefore, willingness to have a resonance relationship involves willingness to take the risk of descending into something for which we do not know what the consequences will be. Resonance presupposes readiness for risk and vulnerability, or willingness to make myself vulnerable. It also involves, as already mentioned, a certain loss of autonomy and control. In terms of the outlined readiness for a resonance relationship, Rosa speaks of dispositional resonance or habitual resonance readiness. Dispositional resonances or resonance attitudes, however, are not cultivated by those who perceive the world as hostile, because emotional attitudes, which correspond to the perception of the world as hostile, are characterized by emotional closedness, affective defensive attitude and readiness for combat. Resonance attitude towards the world requires a certain degree of sympathy for the world or love for it and perception of the world not as something that is foreign to me, but as something related to me. Resonance attitude also presupposes certain optimism and trust. The last claim is to some extent confirmed by Rosa's words that dispositional alienation may also be the result of a lack of experience of one's own self-efficacy: whoever, on the basis of their own life experience, assumes that they can't reach the other, but rather they must assert themselves against them or defend themselves against the other, they will find it difficult to cultivate a resonance attitude (Rosa, 2019a: 27-28).

\section{Conclusion}

The above comparative analysis of the concepts of resilience and resonance confirms my main thesis. We can see that human resilience without resonance is not possible and that there are many key characteristics that are common to both resilience and resonance: affection, inaccessibility, uncontrollability, transformation, self-efficacy, openness, sensibility (for one another), responsiveness (Rosa, 2019a: 15), vulnerability, trust, sympathy or love of the world, and many others. The fact that there are these common features is another indicator of the close connection between the two.

Finally, let me add some clarifications and supplements in order to make the article and its point more understandable and avoid eventual misunderstandings and misinterpretations.

The first clarification concerns the contribution of the article to Rosa's theory of resonance. I would like to stress that my main aim in this paper is not to broaden or elaborate Rosa's theory of resonance. The focus of the article is on proving the thesis that resonance is an integral part of human resilience. To prove this, I have had to present in the article an analysis of both, the notion of resonance and the notion of resilience. The concept of resonance has been so far treated most comprehensively and systematically by Hartmut Rosa, so I took his theory of resonance as a basis and presented it in the article. However, despite the focus on my main thesis, the article is not only a contribution to the understanding of resilience, but also contributes to a broader understanding of (Rosa's) notion of resonance by connecting it to the notion of resilience and showing the latter's dependence on resonance. Rosa himself has not done this (explicitly). However, since both the notion of resonance and the notion of resilience are at the heart of modern humanities research, they are, so to speak, two paradigmatic notions and hot topics of contemporary humanities, I believe that such an explication, as a classical task of philosophical (conceptual) analysis, is interesting and useful. Especially because it is not self-evident, which is obvious from the fact 
that some authors contrast resilience and resonance as two alternatives (Klun, 2020), while I proved in the article the opposite, namely that resonance is an integral part of resilience.

The second clarification concerns the type of analysis I perform in the article. As first, we may say that it is a conceptual philosophical analysis, as it is well explained by the definition in The Penguin Dictionary of Philosophy:

»(In philosophy) conceptual analysis, or philosophical analysis, is, in general, the process (or its result) of explaining, a belief, a theory, etc. by drawing attention to its constituents, its presuppositions, its implications, etc. This can in turn serve as a basis for a critical assessment." (Mautner, 2000: 18)

Another feature of the analysis in this paper is that it is a mereological analysis. Mereology is the science of parts and wholes and the (kinds) of dependencies between them. Mereological analysis has a long tradition in Western philosophy. It was very important already for Aristotle. The examples of mereological analysis one can find in the work of great connoisseur of Aristotle and Edmund Husserl's "teacher" Franz Brentano (e.g. Kategorienlehre). The "classical" text on mereology is Husserl's third logical investigation titled Zur Lehre von den Ganzen und Teilen, which by his own words represents the best point of entry into his philosophy (Husserl 1992: 227-300). In this article, I explored the relationship (of dependence) between resilience and resonance, their components, and their relevant factors. This mereological analysis has led me to the conclusion that human resilience depends on the fact that man is in resonant relations with himself and his environment, in all dimensions: horizontal, vertical and diagonal. I have singled out classical theological virtues as important factors of resilience. This implies the following findings or it is important in the following respects: it first points to the importance of religion for human resilience, illuminating religion as a factor of resilience. Secondly, the analysis of resilience from the point of view of its dependence on virtues connects resilience with the virtue ethics, thus opening a wide field for further research on resilience in various directions, as virtue ethics is one of the leading ethical areas, not just in Western thought and not only in the past, but also in contemporary philosophy.

An integral part of human resonance is vulnerability. It follows from my main thesis that vulnerability is therefore an integral part of human resilience. Thus, the findings of the article pave a way for linking traditional and modern research on vulnerability with the study of human resilience, and show that thinking which seeks the path to human resilience merely in reducing human vulnerability is misguided. This opens up interesting possibilities for research in relation to the meaning of suffering, contemporary debates on transhumanism, and many others.

\section{Acknowledgment}

The Research Programme Ethical-religious Grounds and Perspectives of the Society and the Religious Studies in Context of Education and Violence (P6-0269) and the basic research projects Holistic approach to business and human rights: a normative reform of Slovenian and international legal order (J5-1790), and Interreligious Dialogue - a Basis for Coexisting Diversity in the Light of Migration and the Refugee Crisis (J6-9393) are financed by the Slovenian Research Agency. This article was published with the support of the mentioned programme and projects. I thank the agency for the support.

\section{Bibliographic references}

AMBROSY, M. - KREMPASKY, J. - KALUGINA, O. A. - SIZOVA, Z. A. KROKHINA, J. A. - VALCO, M. 2020. Christianity and Information: Contribution of Stephen Hawking to Physics, Philosophical Ethics, and Theology. In: Bogoslovni vestnik, vol. 80, n. 4, pp. 901-914. ISSN 0006-5722.

XLinguae, Volume 14 Issue 3, June 2021, ISSN 1337-8384, eISSN 2453-711X 
ANTONOVSKY, A. 1979. Health, Stress and Coping. San Francisco: Jossey-Bass Publishers. ISBN 978- 0875894126.

ANTONOVSKY, A. 1997. Salutogenese. Zur Entmystifizierung der Gesundheit. Tübingen: DGTV. ISBN 978-3871591365.

BOGACZYK-VORMAYR, M. 2012. Vom Scheitern und Neubeginnen. Ein philosophischer Beitrag zur Resilienzforschung. Salzburger Beiträge zur Sozialethik, n. 1. ISSN 2304-327X. Available online: http://www.ifzsalzburg.at/uploads/WP.Vormayr.SBSE.1.20121.pdf

BRENTANO, F. 1985. Kategorienlehre. Hamburg: Felix Meiner Verlag. ISBN 37873-0011-2.

BUBER, M. 1995. Ich und Du. Stuttgart: Reclam. ISBN 978-3-15-009342-9.

BUBER, M. 1999. Dialoški princip [Ger. original Das dialogische Prinzip]. Ljubljana: Društvo 2000. ISBN 961-90649-3-3.

GRAEFE, S. 2019. Subjective limits to growth and the limits to a lifestyle oriented critique of growth. In: The Good Life Beyond Growth: New Perspectives, eds. Hartmut Rosa and Christoph Henning. New York et al.: Routledge, pp. 201-211. ISBN 978-0-367-34044-5.

HIEKE, T. 2009. 'Glaubt ihr nicht, so bleibt ihr nicht' (Jes 7,9). Die Rede vom Glauben im Alten Testament. In: Theologie und Glaube, vol. 99, pp. 27-41. ISSN 0049-366X. Available online: http://www.theologie-undglaube.de/fileadmin/documents/leseproben/02Hieke.pdf

HORX, M. 2011. Das Megatrendprinzip. Wie die Welt von morgen entsteht. München: Deutsche Verlags-Anstalt. ISBN 978-3421044433.

HUSSERL, E. 1992. Logische Untersuchungen. Zweiter Band. I. Teil. Hamburg: Felix Meiner Verlag. ISBN 3-7873-1094-0.

KLADEN, T. - SCHUßLER, M. (eds.). 2017. Zu schnell für Gott? Theologische Kontroversen zu Beschleunigung und Resonanz. Freiburg et al.: Herder. ISBN 978-3451-02286-9.

KLUN, B. 2020. Rezilienca in resonanca: v iskanju nove drže do sveta. In: Bogoslovni vestnik, vol. 80, n. 2, pp. 281-292. ISSN 0006-5722.

NGUYEN, Q. H. - VALCOVA, K. - ZAKIROVA, V. G. - LARIONOVA, A. A. LAPIDUS, N. I. 2020. Western science, religion and Vietnamese traditional culture: harmony or antagonism? In: XLinguae, vol. 13, n. 3, pp. 94-113. ISSN 1337-8384.

MAUTNER, T. (ed.). 2000. The Penguin Dictionary of Philosophy. London: Penguin Books. ISBN 0-14-051250-0.

NGUYEN, T. T. - TRUONG, Q. T. T. - VALCO, M. - KHVATOVA, M. K. TYAZHELNIKOV, A. A. 2020. Christian Theological Views on Industrial Revolutions and Related Ethical Challenges: A Western (and a Global) Perspective. Bogoslovni vestnik, vol. 80, n. 1, pp. 177-190. ISSN 0006-5722.

PAVLIKOVA, M. - TIBOR, M. 2020. Auden's creative collision with Kierkegaard. In: XLinguae, vol. 13, n. 3, pp. 145 - 156. ISSN 1337-8384.

PETERS, C.H. - SCHULZ, P. (eds.). 2017. Resonazen und Dissonanzen. Hartmut Rosas kritische Theorie in der Diskussion. 2017. Bielefeld: transcript Verlag. ISBN 978-3-8376-3565-2.

PETKOVSEK, R. 2019. Teologija pred izzivi sodobne antropološke krize: preambula apostolske konstitucije Veritatis gaudium. In: Bogoslovni vestnik, vol. 79, n. 1, pp. 17-31. ISSN 0006-5722.

PLATOVNJAK, I. 2017. Vpliv religije in kulture na duhovnost in obratno. In: Bogoslovni vestnik 77, n. 2, pp. 337-344. ISSN 0006 - 5722.

PLATOVNJAK, I. - SVETELJ, T. 2019. To Live a Life in Christ's Way: the Answer to a Truncated View of Transhumanism on Human Life. In: Bogoslovni vestnik, vol. 79, n. 3, pp. 669-682. ISSN $0006-5722$.

RIFKIN, J. 2020. We are now facing in real time how fast the global economy can collapse. David Torcasso's interview with Jeremy Rifkin. In: Handelszeitung, April 
$3^{\text {rd }}$. Available online: https://www.handelszeitung.ch/unternehmen/jeremy-rifkin-weare-now-facing-real-time-how-fast-global-economy-can-collapse

ROSA, H. 2016. Resonanz. Eine Soziologie der Weltbeziehung. Berlin: Suhrkamp. ISBN 978-3-518-29872-5.

ROSA, H. 2018. Unverfügbarkeit. Wien: Residenz Verlag. ISBN 9783701734467.

ROSA, H. 2019a. Resonanz als Schlüsselbegriff der Sozialtheorie. In: Resonanz. Im interdisziplinären Gespräch mit Hartmut Rosa, ed. J.-P. Wils. Baden-Baden: Nomos, pp. 11-30. ISBN 978-3-8487-4645-3.

ROSA, H. 2019b. Zur Kritik und Weiterentwicklung des Resonanzkonzepts. In: J.-P. Wils (ed.), Resonanz. Im interdisziplinären Gespräch mit Hartmut Rosa. Baden-Baden: Nomos, pp. 191-212. ISBN 978-3-8487-4645-3.

ROSA, H. 2019c. Resonance: A Sociology of our Relationship to the World. Cambridge, UK and Medford, MA, USA: Polity Press. ISBN 978-1-5095-1989-7.

ROSA, H. 2019d. Available, accessible, attainable: the mindset of growth and the resonance conception of the good life. In: H. Rosa and C. Henning (eds.), The Good Life Beyond Growth: New Perspectives. New York et al. Routledge, pp. 39-53. ISBN 978-0-367-34044-5.

ROSA, H. - HENNING, C. (eds.). 2019. The Good Life Beyond Growth: New Perspectives, eds. Hartmut Rosa and Christoph Henning. New York et al. Routledge. ISBN 978-0-367-34044-5.

ROUBALOVA, M. - KALUGINA, O. A. - KRALIK, R. - KONDRLA, P. 2020. The end of the Kingdom of Judah and its echoes in the Jewish calendar. In: XLinguae, vol. 13, n. 3, pp. 14-205. ISSN 1337-8384.

SAUTERMEISTER, J. 2016. Resilienz zwischen Selbstoptimierung und Identitätsbildung. In: Münchener Theologische Zeitschrift, vol. 67, n. 3, pp. 209-223. ISSN 0580-1400.

SCHNEIDER, M. - VOGT, M. 2016. Glaube, Hoffnung, Liebe als Resilienzfaktoren. Theologisch-ethische Erkundungen. In: Münchener Theologische Zeitschrift, vol. 67, n. 3, pp. 195-208. ISSN 0580-1400.

SEDMAK, C. 2013. Innerlichkeit und Kraft. Studie über epistemische Resilienz. Freiburg/Br.: Herder. ISBN 9783451341465.

STRAHOVNIK, V. 2018. Spoznavna (ne)pravičnost, krepost spoznavne ponižnosti in monoteizem. In: Bogoslovni vestnik, vol. 78, n. 2, pp. 299-311. ISSN 0006-5722.

TAVILLA, I. - KRALIK, R. - ROUBALOVA, M. 2019. Abraham and the tortoise: Eleatic variations on Fear and Trembling. In: XLinguae, vol. 12, n. 4, pp. 219-228. ISSN 1337-8384.

TAYLOR, C. 2019. The Ethical Implications of Resonance Theory. In: J.-P. Wils (ed.), Resonanz. Im interdisziplinären Gespräch mit Hartmut Rosa. Baden-Baden: Nomos, pp. 71-85. ISBN 978-3-8487-4645-3.

VODICAR, J. 2017. Ziva metafora kot možna pot do transcendence. In: Bogoslovni vestnik, vol. 77, n. 3-4, pp. 565-576.

VOGT, M. 2015. Zauberwort Resilienz. Eine Begriffsklärung (Bayerischer Forschungsverbund For Change, Working Paper 2). Available online: http://resilienz.hypotheses.org/wp2

VOGT, M. - SCHNEIDER, M. 2016. Zauberwort Resilienz. Analysen zum interdisziplinären Gehalt eines schillernden Begriffs. In: Münchener Theologische Zeitschrift, vol. 67, n. 3, pp. 180-194.

WILS, J.-P. (ed.). 2019. Resonanz. Im interdisziplinären Gespräch mit Hartmut Rosa. Baden-Baden: Nomos. ISBN 978-3-8487-4645-3.

Words: 6576

Characters: 43131 (23,96 standard pages)

XLinguae, Volume 14 Issue 3, June 2021, ISSN 1337-8384, eISSN 2453-711X 
Prof. Bojan Žalec, PhD

Faculty of Theology

University of Ljubljana

Poljanska c. 4, 1000 Ljubljana

Slovenia

bojan.zalec@teof.uni-lj.si 